\title{
Retinopathy of prematurity: inflammation, choroidal degeneration, and novel promising therapeutic strategies
}

\author{
José Carlos Rivera ${ }^{1,2^{*}+}$, Mari Holm ${ }^{3 \dagger}$, Dordi Austeng ${ }^{4,5}$, Tora Sund Morken ${ }^{3}$, Tianwei (Ellen) Zhou, ${ }^{1,2}$, \\ Alexandra Beaudry-Richard ${ }^{1}$, Estefania Marin Sierra ${ }^{1}$, Olaf Dammann ${ }^{6,7}$ and Sylvain Chemtob ${ }^{1,2^{*}}$
}

\begin{abstract}
Retinopathy of prematurity (ROP) is an important cause of childhood blindness globally, and the incidence is rising. The disease is characterized by initial arrested retinal vascularization followed by neovascularization and ensuing retinal detachment causing permanent visual loss. Although neovascularization can be effectively treated via retinal laser ablation, it is unknown which children are at risk of entering this vision-threatening phase of the disease. Laser ablation may itself induce visual field deficits, and there is therefore a need to identify targets for novel and less destructive treatments of ROP. Inflammation is considered a key contributor to the pathogenesis of ROP. A large proportion of preterm infants with ROP will have residual visual loss linked to loss of photoreceptor (PR) and the integrity of the retinal pigment epithelium (RPE) in the macular region. Recent studies using animal models of ROP suggest that choroidal degeneration may be associated with a loss of integrity of the outer retina, a phenomenon so far largely undescribed in ROP pathogenesis. In this review, we highlight inflammatory and neuron-derived factors related to ROP progression, as well, potential targets for new treatment strategies. We also introduce choroidal degeneration as a significant cause of residual visual loss following ROP. We propose that ROP should no longer be considered an inner retinal vasculopathy only, but also a disease of choroidal degeneration affecting both retinal pigment epithelium and photoreceptor integrity.
\end{abstract}

Keywords: Inflammation, Neuron-derived factors, Choroidal degeneration, Retinopathy of prematurity

\section{Background}

Retinopathy of prematurity (ROP) represents an important cause of childhood blindness worldwide [1, 2]. In highincome countries, ROP-associated blindness incidence has been reported to be lower than $10 \%$ of extremely preterm born children; however, in low- and particularly middleincome countries, the incidence is greater than $40 \%$ with increasing survival of infants born preterm and limited fundoscopic follow-up evaluation [3-5].

ROP is considered a multifactorial disease, and its pathogenesis has been extensively studied in humans and in several animal models. In premature infants, the development of ROP proceeds with an initial phase of retinal microvascular degeneration $[6,7]$ associated with

\footnotetext{
*Correspondence: jc.rivera@umontreal.ca; sylvain.chemtob@umontreal.ca ${ }^{\dagger}$ Equal contributors

'Department of Pediatrics, Ophthalmology and Pharmacology, Centre Hospitalier Universitaire Sainte-Justine Research Center, 3175, Chemin Côte Ste-Catherine, Montréal, Québec, Canada

Full list of author information is available at the end of the article
}

an arrest in progressive vascularization of the peripheral retina. These vascular changes result in retinal ischemia which predisposes to abnormal intravitreal neovascularization leading to its most significant sequelae retinal detachment and permanent visual loss. Even though pathological neovascularization in ROP may be prevented with treatment limiting tissue ischemia (laser ablation of the retina) and/or hypersecretion of VEGF (intravitreal injection of anti-VEGF), still a clear understanding of the mechanisms implicated in the progression of ROP from phase 1 to phase 2 is needed to develop new therapeutic alternatives. So far, several risk factors in the initial phase of ROP have been discussed [8, 9]. For instance other than prematurity, growth restriction is in addition to hyperoxia, an established risk-factor for ROP development $[10,11]$. According to this, the WINROP tool (weight, insulin-like growth factor I, neonatal, retinopathy of prematurity) based on neonatal growth and measurements of levels of insulin-like growth factor-1 (IGF-1) has recently been 
developed as a prognostic marker [12]. On the other hand, it is known that premature neonates are susceptible to infection because of immature immune system. Inflammation has been shown to play an important role in the development of normal and pathological angiogenesis in the retina [13-16]. Interestingly, in the last 5 years, a series of epidemiological studies have supported the hypothesis that neonatal inflammation is a key modulator in the development and progression of ROP [17-19]. In the ELGAN study cohort, inflammatory stimuli such as bacteria in the placenta [20] and late bacteremia [21] were risk factors for developing ROP. Moreover, systemic inflammation in neonates has been shown to perturb retinal vessel development and to induce pathological features of ROP in animal models [22, 23]. Inflammatory factors such as cytokines, chemokines, hypoxia-inducible factors, hormones, nitric oxide, growth factors, or inflammatory cells such as leucocytes, monocytes, or macrophages/microglia are implicated in the control of angiogenesis and/or play a detrimental role in the developing vasculature $[24,25]$. Furthermore, the influence of inflammation in the regulation of neuron-derived signaling molecules that causes endothelial cell injury during ROP has recently been highlighted. Notably, the beneficial or detrimental effect of all these components may depend on the time of action, duration, concentrations, and target tissue.

The retina is essentially an outgrowth of the brain where neural and vascular tissue develops in close proximity during fetal and neonatal life [26]. It is therefore conceivable that pathological processes that occur in the developing retina also can occur in the brain. An example of this is the augmented inflammatory response associated with retinal and preterm brain injury during hypoxia-ischemia [27, 28]. Therefore, in addition to the risk of a poor visual outcome, infants with ROP are at increased risk of dysfunctions associated with non-visual disabilities such as brain damage [29], physical and cognitive impairment at 5 years [30,31], below-grade-level academic performance at 8 years [32], and lower healthrelated quality of life at 10 years of age [33]. In fact, approximately $55 \%$ of children with ROP sustain long-term neurodevelopmental disabilities [34]. These studies suggest a shared etiology of visual and non-visual developmental disabilities in preterm born children. Consequently, expanding the knowledge of ROP pathogenesis has the potential to contribute to preventing both the pathological vascularization and the risk of retinal detachment in ROP, as well as the complications and diseases that are associated with ROP.

An enigma on long-term outcome following ROP has been the residual visual loss that may occur in patients regardless of regression of neovascular changes. Indeed, there are indications that ROP affects the late-maturing central retina with long-term deficits in photoreceptorfunctioning [35, 36]. The choroid supplies the central outer retina with oxygen and nutrients, and deficits in choroidal maturation could participate in visual deficits following ROP [35]. Knowledge on how choroidal degeneration influences the integrity of the retinal pigment epithelium (RPE) and photoreceptor layers might be important in understanding the long-term damages following ROP, such as residual visual loss.

The present review addresses established concepts as well as emerging evidence implicating inflammation in the pathogenesis of ROP, the detection of choroidal degeneration and possible consequences in ROP, and some promising therapeutic strategies for this disorder.

\section{Inflammatory factors in ROP}

The role of inflammation in ROP has been poorly investigated. Recent evidences suggested that prenatal, perinatal, and postnatal inflammation might contribute to a gradual increase in the risk for ROP [17]. Cytokines and chemokines are small proteins secreted by immune cells that play a central role in distinct inflammatory processes including the progression of ROP. Current evidences about the role of these inflammatory factors in the development of ROP will be discussed in the following section.

\section{Cytokines}

Both the fetus and the preterm newborn are capable of mounting a significant inflammatory response [37], often linked to maternal infection transmitted to the preterm infant $[38,39]$. The inflammatory response is a highly regulated process, where an elevated concentration of one cytokine often is associated with elevated levels of others (21). Cytokines such as IL- $1 \beta$, TNF- $\alpha$, and IL- 6 act as primary initiators of inflammation following infection or tissue damage [40], although both pro- and antiinflammatory properties have been observed [41]. These initiators of inflammation can mediate cytokine receptor activation, which leads to downstream upregulation of effector molecules such as chemokines (e.g., IL-8, RANTES) and adhesion molecules (e.g., ICAM-1) [42]. Interestingly, IL-1 $\beta$ and TNF- $\alpha$ produced by retinal microglia cells following exposure to hypoxia have been associated with deleterious effects in the retina [43]. In the oxygeninduced retinopathy (OIR) model, IL- $1 \beta$ has been indirectly associated to retinal microvascular degeneration [44]; while in the choroid, it is directly responsible for the involution of the choroidal blood vessels that results in a hypoxic sub-retina and consequently loss of RPE and photoreceptor integrity [45].

IL-10 and IL-4, on the other hand, tend to be viewed as anti-inflammatory cytokines [41], capable of protecting the developing brain and possibly retina against ongoing inflammation. Although, a study showed that 
IL-10 can be implicated in promoting pathological angiogenesis in an OIR mice model [46], conversely, in vitro, IL-10 inhibits expression of TNF- $\alpha$, MIP-1a, and RANTES in microglial cells [47]. Furthermore, in pregnant rats exposed to systemic inflammation, IL-10 treatment reduced the occurrence of brain damage in their newborn pups [48]. Infants with an IL-10 highproducer allele were less likely to have white matter damage on ultrasound and a trend (albeit not significant) towards a lower prevalence of severe ROP [49]. On the other hand, no differences in blood IL-4 concentration were found between infants with ROP and controls in cord blood [50] or vitreous [13]; however, elevated vitreous IL-4 concentrations have been detected in patients with diabetic retinopathy [51].

\section{Chemokines}

Chemokines induce chemotaxis and regulate movements of immune cells such as microglia to sites of inflammation. Chemokines of special interest for ROP pathophysiology are IL-8, RANTES, monocyte chemotactic protein 1 (MCP-1), and interferon-inducible T-cell $\alpha$ chemoattractant (I-TAC).

IL-8 is implicated in both inflammation and neovascularization pathological in the eye [52]. In humans, higher serum concentration of IL- 8 right after birth was associated with later ROP deemed "in need of treatment" [53], whereas in rats, increased levels of an IL- 8 homologue were detected during the peak of pathological neovascularization in a model of ROP [54].

RANTES plays an important role in innate immunity, which is particularly critical to the newborn until acquired immunity is developed. The role of RANTES in ROP development is not known; however, it has been found that the concentration of RANTES in the vitreous of eyes with vasoproliferative severe ROP tends to be low [13], and a lower serum level was detected in infants who later developed severe ROP $[14,55]$. These data suggest that RANTES might play an important protective role during ROP, which warrants further investigation.

MCP-1 can attract a variety of immune cells and is expressed in a wide range of tissues including neurons, astrocytes, and activated microglia of the brain and neuroretina [56]. MCP-1 has the ability to disrupt the bloodbrain barrier and is thought to contribute to the pathogenesis of multiple neurodegenerative diseases [56]. Preterm infants who later developed ROP tended to have higher cord serum concentrations of MCP-1 than both healthy preterm peers and infants born at term [57]. Among newborns who weighed $<1000 \mathrm{~g}$, those who received/needed oxygen for more than $6 \mathrm{~h}$ had higher MCP-1 concentrations in blood collected on day 3 than their peers who received oxygen for a shorter amount of time (even after adjusting for potential confounders) [58]. In addition, several studies documented elevated levels of MCP-1 in the vitreous humor of patients with retinopathy $[59,60]$, and in animal models, MCP-1 was shown to be involved in the induction of the retinal neovascularization possibly by modulating or attracting macrophages/microglia during the ischemic phase of retinopathy $[61,62]$.

\section{Growth factors}

Vascular endothelial growth factor (VEGF) and insulinlike growth factor-1 (IGF-1) have long been considered some of the main actors in the pathogenesis of ROP. However, recent research data suggest that neurotrophins, matrix metalloproteinases, HIFs, erythropoietin (EPO), placental growth factor (PlGF), basic fibroblast growth factors, angiopoietins, and thyroid-stimulating hormone (TSH) also play a significant role in the progression of ROP. Some of these evidences will be discussed below.

\section{Neurotrophins: brain-derived neurotrophic factor and neurotropin 4}

Neurotrophins belong to a family of growth factors that promote neuronal survival and differentiation both in the central and peripheral nervous systems [63]. Infants who developed severe ROP tended to have lower serum concentrations of neurotrophin-4 and brain-derived neurotrophic factor (BDNF) during the first 3 weeks of life than those who did not develop severe ROP [14]. In the same study cohort, specific gene variations of BDNF were associated with threshold ROP [64]. In a separate small study, 16 infants who developed ROP had lower BDNF concentrations than 7 who did not develop ROP on postnatal day 60 [65].

\section{Metalloproteinases}

The matrix metalloproteinases (MMP-1 and MMP-9), which are responsible for cleaving protein in the extracellular matrix, are important in fetal development, inflammatory responses, and angiogenesis [66, 67]. Factors that are implicated in preterm diseases such as reactive oxygen species (ROS), growth factors, and various cytokines initiate MMP transcription [68] thereby making metalloproteinases (MMPs) biomarkers of interest for ROP. Systemic inhibition of MMPs in mice reduced neovascularization in an OIR model, while increased concentrations of proteases in the retina (MMPs included) have been associated with the active phase of retinopathy [69].

\section{HIF1- $a$ and HIF2- $a$}

HIFs are transcription factors that stimulate the release of a wide variety of growth factors such as members of the VEGF family, angiopoietins, and EPO. The $\alpha$-subunits of HIF-1 and HIF-2 are of special interest in ROP pathogenesis since they are suppressed during hyperoxia (ROP phase 1) and upregulated by tissue hypoxia (ROP phase 2) 
$[66,70]$. In mice, prevention of HIF- $1 \alpha$ degradation in the hyperoxic phase 1 might prevent hyperoxia-related vessel loss [71], whereas drug-induced reduction of HIF-1 during the neovascular phase (phase 2) appears to reduce retinal neovascularization [72].

\section{VEGF and its receptors (VEGFR 1 and 2)}

VEGF is a sub-family of growth factors involved in the developing retinal vasculature. The active role of VEGF in ROP pathogenesis seems well established and is supported by both clinical studies [73, 74], and the benefits of intravitreal anti-VEGF injections during the neovascular phase of ROP [75]. While suppressed during the hyperoxic phase 1 in ROP development, high VEGF levels in phase 2 disturb normal vascularization. VEGF production is stimulated by hypoxia-induced transcription factors such as HIF- $1 \alpha$ and HIF- $2 \alpha$, but both oxygen treatment and systemic diseases such as respiratory distress trigger VEGF production [76].

Although the role of VEGF is established in both ROP development and treatment, the role of VEGF receptors (VEGFR 1 and 2) is less clear. VEGFRs promote the differentiation of endothelial cells, are important in angiogenesis, and their expression is increased by hypoxia and potentiated by VEGF [77]. In a small study measuring plasma levels of VEGF and VEGF-receptor 1 and 2, only VEGFR2 was elevated in ROP patients (severe ROP was not analyzed separately) [78]. In another study, ROP was associated with an increase in VEGF and VEGF-R2 expression and blood vessel growth [79]. Conversely, in a model of OIR in rats, a VEGF-R2 inhibitor reduced intravitreal neovascularization [80].

\section{Erythropoietin}

EPO has multiple functions in the fetus and the newborn and was originally viewed as a hematopoietic hormone exclusively stimulating the production of erythrocytes [81]. Since then, other important functions of EPO have been identified i.e., related to the development of the brain, retina, cardiovascular [82], and gastrointestinal systems [83]. In preterm newborns, recombinant human EPO (rh-EPO) is used to reduce transfusion requirements [84] and appears to attenuate the risk of brain damage $[85,86]$, apparently through anti-inflammatory, anti-excitatory, and neuroproliferative pathways $[87,88]$. Among preterm newborn, those who have elevated concentrations of endogenous EPO are more likely than others to have elevated concentrations of inflammation-related proteins in concurrent blood specimens [89]. Elevated EPO concentrations in the blood of infants born before gestation week 28 were associated with a variety of morbidities including ROP and respiratory problems occurring later [90]. It is possible that EPO plays a direct role in stimulating angiogenesis and is consistent with high EPO concentrations before ROP-associated neovascularization occurs [17, 21, 91].

EPO and its receptors are present in the retina, but the role of EPO in ROP pathogenesis remains to be clarified [84]. Meta-analyses report an increased risk of severe ROP with EPO-treatment [84]. Like VEGF, EPO is a potent angiogenic factor, and its production is induced by HIFs. It is conceivable that EPO plays different roles in the different phases of ROP development [92]. For instance, low concentrations of EPO in phase 1 contribute to a stop in angiogenesis, while elevated levels in phase 2 enhance pathological neovascularization. The concentration of EPO in the vitreous is correlated with that of VEGF and is elevated in the vasoproliferative phase of ROP [73].

\section{Insulin-like growth factor 1}

Insulin-like growth factor (IGF-1) is a hormone important for fetal growth, including healthy retinal angiogenesis [93]. IGF-1 is also probably necessary for normal VEGF function [94]. Importantly, the placenta and amniotic fluid are the main sources of IGF-1 during development in utero, such that after birth, IGF-1 levels decrease precipitously in premature infants $[95,96]$. Inflammation is another factor that may further reduce the preterm newborn's limited IGF-1 production [97]. Low systemic serum IGF-1 concentration is a risk factor of ROP development and is a biomarker that identifies infants at risk weeks before disease manifests [98]. Low IGF-1 serum levels are associated with retinal vessel growth delay, which is directly correlated with the severity of ROP [96]; interestingly, IGF-1 binding protein (IGFB3) was also found to be decreased in premature infants and may also contribute to retinal vessel depletion [96].

\section{Placental growth factor}

Placental growth factor (PlGF) is a protein in the vascular growth factor family and is upregulated in pathological angiogenesis. It is, presumably, an important cofactor for retinal neovascularization, but PlGF also plays a role in recruiting immune cells $[99,100]$. Unlike its siblings in the VEGF-family, PIGF is downregulated during hypoxia and exerts an anti-apoptotic effect during hyperoxia. PIGF is therefore suggested to be important during the aberrant neovascular phase of ROP [101]. In a mouse retinopathy model, PIGF deficiency reduces pathological vascular leakage [102]. To add to this complexity, PlGF expression is increased upon treatment with anti-VEGF (bevacizumab) [99].

\section{Basic fibroblast growth factor (bFGF / FGF-2)}

Basic fibroblast growth factor (bFGF) is a potent stimulant of neuronal and endothelial proliferation and is expressed during vascular [103] and retinal [104] development. Akin to PlGF, expression of bFGF was downregulated when 
VEGF increases in cultured cells [105] and in mice with retinopathy [106]. Results from studies on bFGF are conflicting. A tendency of lower concentrations of bFGF was found in the vitreous of infants undergoing vitrectomy due to severe ROP compared to infants undergoing vitrectomy at term due to congenital cataract [13]. Increased retinal bFGF expression was detected in a mouse model of OIR [106], and retinal neuroprotective effects of bFGF are detected in various animal models $[107,108]$. Still, other studies have reported that bFGF does not contribute to either the preservation of a healthy retina or to pathological neovascularization in animal models [109].

\section{Angiopoietin 1 and 2}

Ang1 and Ang2, vascular growth factors important both in fetal life and after birth, remodel the developing vasculature and contribute to vessel stability. Both are ligands of the Tie2 receptor, although in an agonist (Ang1) and antagonistic fashion (Ang2). When Tie2 and VEGF were inhibited together, retinal angiogenesis was more efficiently suppressed than with VEGF inhibition alone [110]. Whereas Ang1 promotes vascular maturation and stability, Ang2 works to initiate neovascularization [110, 111]. The concentration of Ang1 and Ang2 is negatively correlated in the vitreous of eyes with severe ROP, where Ang2 concentration was significantly increased [112]. These findings set the balance between Ang1 and Ang2 in ROP pathogenesis.

\section{Thyroid-stimulating hormone}

Thyroid function is essential for brain [113] and retinal [114] development. An association is found between neonatal hypothyroidism in preterm born children and poor neurodevelopmental outcome at 3 months and visual problems at 6 months [115]. However, in line with unclear definition of hypothyroidism in preterm infants, low T4 is not consistently associated with altered cognitive function compared to their euthyroid peers at age 7 [116]. When it comes to thyroid function and ROP pathogenesis, prophylactic supplementation of thyroid hormone has not reduced ROP prevalence [117]. Further on, hyperthyrotropin was associated with brain damage when occurring together with an inflammatory reaction [118], and it appears to contribute to both the onset and outcome of the inflammatory process [119]. Yet, both TSH and the thyroid function could be of interest in future ROP research.

\section{Semaphorins and ROP}

The influence of neuron-derived signaling molecules on endothelial cell injury during ROP has recently been highlighted [44, 120, 121]. Classic neuronal guidance cues and their receptors, particularly class III semaphorins [122], a large family of conserved proteins originally implicated in axonal guidance, could act as repulsive molecules in the hypoxic area of the retina during retinopathy, thus hindering normal vascularization and contributing to the formation of abnormal vascular tufts [120]. The pathological mechanism that involve semaphorins in ROP is initiated when the resting microglia cells become activated in the ischemic areas of the retina and trigger the secretion of pro-inflammatory cytokines, particularly IL-1 that stimulate the production of pro-apoptotic/repulsive factor Semaphorin3A (Sema3A) specifically in retinal ganglion neurons $[44,120]$. Augmentation of Sema3A in areas of ischemia then contributes to the vascular decay and forms a chemical barrier that repels neo-vessels towards the vitreous. Conversely, IL-1 receptor antagonist [44] or silencing Sema3A expression enhances normal vascular regeneration within the ischemic retina, thereby preserving neuroretinal function and diminishing aberrant pre-retinal neovascularization. Therefore, overcoming the chemical barrier erected by Sema3A accelerates the vascular regeneration of neural tissues, which restores metabolic supply, improves retinal function, and reduces the risk for abnormal intra-vitreal neovascularization.

In a similar manner to Sema3A, Wei et al. [123] recently showed that absence of neuronal Nrf2, a major stress-response transcription factor responsible for cellintrinsic cytoprotective function, results in Sema6A induction in hypoxic/ischemic retinal ganglion cells that diminished normal revascularization into the avascular zones in the inner retina from ROP animals. Interestingly, lentiviral-mediated delivery of Sema6A small hairpin RNA (shRNA) abrogated the defective retinal revascularization in Nrf2-deficient mice. Importantly, pharmacologic Nrf2 activation promotes reparative angiogenesis and suppresses pathologic neovascularization [123]. These findings reveal a unique function of $\mathrm{Nrf} 2$ in reprogramming ischemic tissue towards neurovascular repair via Sema6A regulation, providing a potential therapeutic strategy for ischemic retinal diseases.

Other studies have also highlighted the anti-angiogenic properties of semaphorins. Fukushima [124] found that Sema3E expressed in retinal neurons guides normal and pathological vessels through its receptor Plexin-D1. In the OIR model, increased PlexinD1 expression in neovessels prevents VEGF-induced disoriented projections of endothelial filopodia. Of greater therapeutic significance, intravitreal administration of Sema3E suppressed pathological neovascularization, while preserving the desired regeneration of the retinal vasculature into ischemic retinal areas. The same effect occurs with the intravitreal administration of Sema3C. Yang [125] demonstrated that Sema3C acting through the receptors Neuropilin-1 and PlexinD1, which are strongly expressed on vascular tufts, induced VE-cadherin internalization and abrogated VEGF-induced activation of the kinases AKT, FAK, 
and p38MAPK. This resulted in a disrupted endothelial tip cell formation and cell-cell contacts that inhibited the formation of pathological pre-retinal vascular tufts during OIR. All these findings suggest that semaphorins are potential targets to be explored in the clinic setting to prevent ROP.

\section{Choroidal degeneration in ROP}

At present, the inner retina has been considered the primary region affected in human ROP and animal models. However, it is known that dysfunction of the outer retina occur in a number of older children formerly afflicted with ROP [126-129]. Hence, with increasing survival of extremely premature neonates (at risk of ROP) [130], an insidious recognition of progressive outer retinal dysfunctions [126, 127] is being observed in former ROP patients, requiring follow-up beyond childhood [131, 132], as recently reviewed [133].

In recent years, several clinical and animal studies have reported extensive choroidal vascular degeneration associated with ROP development. Because choroidal vasculature is the exclusive source of oxygen and nutrients to the photoreceptors and RPE cells, it has been proposed that involution of the choroid may be associated with residual visual loss following ROP [35], as it leads to marked sub-retinal hypoxia [45]. In support of this inference, we have demonstrated that choroidal degeneration which occurs in the first postnatal week during OIR is followed weeks later by a loss in RPE integrity and a degeneration of photoreceptors [45]. Consistent with these observations, a number of recent clinical studies in older children and young adults revealed using optical coherence tomography a $>25 \%$ choroidal thinning in former ROP patients [132, 134-137]; importantly, this choroidal thinning is first detected in the human newborn [137], as documented in animal models of ROP [35]. Hence the vasculopathy seen in ROP affects not only the inner retina but also the choroid-important for RPE and photoreceptor integrity.

The mechanism of choroidal involution in ROP has been poorly explored. Shao et al. [35] demonstrated that a sustained degeneration of the choroid in different animal models of ROP is largely through the actions of the electrophile 15-deoxy-12,14-PGJ2 (15d-PGJ2), a nonenzymatic product of prostaglandin D2 (PGD2) that provokes apoptotic death in endothelial cells by inducing oxidant stress. Importantly, choroidal circulation in newborn animals is significantly controlled by high local levels of prostaglandin D2 (PGD2) [138, 139], which, in turn, curtails the autoregulation of choroidal blood flow in response to hyperoxic exposure, resulting in increased oxygenation of the outer retina [140]. Notably, a high density of PGD2 receptors is found in the choroid
[141, 142]. The ensuing oxidative environment, as that seen in the immature subject $[143,144]$, facilitates the nonenzymatic conversion of PGD2 into 15d-PGJ2 [145], which participates in redox cell signaling $[125,146]$ and is cytotoxic to endothelial cells under high concentrations [147].

Zhou et al. recently [45] explored the role of IL- $1 \beta$ on choroidal involution and consequently on sub-retinal dysfunction in a ROP model in rodents. In this study, IL-1 $\beta$ was abundantly expressed in the sub-retina of OIR animals and was associated with an early-sustained involution of the choroid, which leads to a markedly hypoxic sub-retina and a progressive loss of RPE and photoreceptors. Early neonatal treatment with IL-1 receptor antagonist preserved choroid, prevented outer retinal hypoxia, and significantly blunted RPE and photoreceptor loss associated with OIR. These observations suggest a critical role for IL-1 $\beta$ (known to trigger prostaglandin synthase expression) in inducing choroidal degeneration and long-term sub- and outer- retinal disorder following OIR/ROP.

Interestingly, it has been noted that choriocapillary involution associated with OIR remains sustained into young adulthood, contrary to inner retinal revascularization that occurs in the middle of the second postnatal week. An additional mechanism may also involve VEGF which is increased in the inner retina during pathological neovascularization, but decreased in the choroids of rats subjected to OIR [35]. Accordingly, choroidal vasculature in preterm newborns continues to develop after exposure to lower oxygen levels [135]; however, high oxygen level exposition leads to less VEGF expression by RPE cells that may contribute to slowing choroidal development resulting in thinner choroid. A recent clinical study has proposed that the time of oxygen exposure is one of the most relevant and negative predictor for choroidal thickness in ROP patients [148]. Concordantly, persistent thin choroid in children with a history of ROP may also reflect a delay in choroidal development. Collectively, these findings highlight the importance and relevance not only of the retinal vasculature but also of that of the choroid as a possible contributor to adverse outcome of ROP.

In line with this concept, it should be pointed out that ROP patients are notorious to developing myopia later in life. Hence, choroid thinning may contribute. Yet in this context, the dioptric change in axial length is altered by a few millimeters [149], whereas thinning of the choroid in humans with ROP is in the range of less than $100 \mu \mathrm{m}$; hence, the choroidal contribution to myopia in ROP cannot be simply attributed to axial length changes, scleral growth, and dioptric shift of the outer laminal membrane should also be accounted for myopic changes in ROP [150]. 


\section{Current and potential therapeutics in ROP Current treatment strategies-laser ablation and anti-VEGF therapy}

As mentioned earlier, peripheral retinal ablation by conventional laser therapy has for many years been the gold standard of ROP treatment. Despite the fact that laser ablation substantially helps prevent blindness, it has moderate effects in eyes with posterior ROP [151], as it may permanently reduce the visual field in addition to inducing myopia [152]. Hence, the development of preventive and less destructive therapies for ROP is desirable. Accordingly, the potential use of anti-VEGF therapy in ROP has been proposed. The anti-VEGF bevacizumab was approved in 2004 by the FDA for treatment of metastatic colorectal cancer. Bevacizumab was shown to inhibit tumor angiogenesis and extend patients' lives by about 5 months when given intravenously as a combination treatment along with standard chemotherapy drugs $[153,154]$. Off-label use of bevacizumab for ocular neovascular diseases started shortly thereafter. In eyes with ROP, it was found to suppress pathological neovascularization in phase 2 and an RCT reported in 2011 benefit from bevacizumab injections compared with laser therapy in eyes with the most posterior ROP (in zone 1). Several clinical studies have documented the use of bevacizumab, ranibizumab, pegaptanib, and recently aflibercept as a therapy for the treatment of ROP $[75,155,156]$. A generally favorable outcome has been detected in the majority of the reports; however, in some of the studies, adverse effects such as endophthalmitis, hemorrhage, retinal detachment, and cataract were also reported $[75,155,157]$. Intravitreal injections of anti-VEGF are by many ophthalmologists considered the primary treatment in eyes with posterior ROP $[158,159]$. The main advantages of anti-VEGF therapy over the use of laser include (a) easier administration under topical anesthesia [160-163], (b) less distortion of macula in posterior ROP [160], and (c) preservation of the peripheral retina that allows continuous vascularization of the retina and prevents the peripheral visual field defects of laser ablation [155]. Concerns have, however, been raised regarding the possible ocular and systemic effects of anti-VEGF in the premature infants [164]. Possible disadvantages during the use of anti-VEGF in the clinic or animals models include (a) systemic complications after intravitreal injections [155], (b) delayed vascularization of retina [160], (c) VEGF blockade alone cannot completely eliminate pathological angiogenesis, suggesting that other factors could be involved [165], and (d) the suppression of VEGF in the eye can affect the survival and/or the function of non-vascular cells including neurons [166], Muller cells [167], cilliary body [168], RPE cells, choriocapillaris, and photoreceptors [169]; this aspect is particularly relevant to the developing neonate in phase of troubling follow-up results in patients treated with bevacizumab [170]. Therefore, systematic research to maximize effectiveness while minimizing side effects of anti-VEGF therapy in ROP is still needed, as dose, duration of action, and molecular entity of anti-VEGF need to be considered.

\section{Potential preventive strategies}

Some promising preventive approaches such as supplementation with IGF-1 and omega-3 fatty acids to prevent vascular injury in phase 1 ROP will be discussed below. Likewise, future therapies such as stem cell transplantation and gene therapies may be part of new strategies to treat ROP as well as targeted modulations of the inflammatory response in the preterm born infant.

\section{Serum IGF-1}

Consistent with the evidence that IGF-1 is as strong as predictor of ROP [98], Löfqvist, C. et al. proposed an algorithm named WINROP (weight, insulin-like growth factor I, neonatal, retinopathy of prematurity) in which IGF-I values can be used to screen for infants who might be at risk of ROP [12]. Using serial weight and IGF-1 measurements in a cohort of 50 premature babies, WINROP predicted all infants who later developed ROP by a mean age of 10 weeks [171]; but in other studies, prediction was not perfect, still requiring routine ophthalmologic evaluation based on current standards [172].

Nonetheless, IGF-1 supplementation has begun to be explored in premature babies at risk of ROP. Evidence to support such a trial has been backed by the following observations. Breast feeding increases serum IGF-1 [173]; this may be due to high levels of IGF-1 in human milk and/or to the presence of specific proteolysis of IGF/IGFBP-2 complexes that increase the bioavailability of IGF-1 [174]. In other studies, early fresh-frozen plasma transfusion, as a source of exogenous IGF-1, increased the serum levels of IGF-1 in premature infants and decreased the risk of ROP $[175,176]$. Likewise, administration of rhIGF-1 in mice attenuated OIR [177]. Recently, a randomized, multicenter (phase IIb) clinical trial of continuous infusion of rhIGF-1 has been launched to address whether maintaining normal physiological levels of IGF-1 may prevent ROP (and other neonatal complications) in premature infants (NCT01096784).

\section{Omega-3 supplements}

Polyunsaturated fatty acids (PUFAs) such as docosahexaenoic acid (DHA) and arachidonic acid are fundamental structural components of neuronal and endothelial cells [178] and are required to maintain optimal retinal functions. Connor et al. [179] demonstrated that dietary omega-3 fatty acids protect against pathologic neovascularization in a mouse model of ROP. The protective 
effect of omega-3-PUFAs and their bioactive metabolites was mediated, in part, through suppression of the pro-inflammatory cytokine tumor necrosis factor-alpha (TNF- $\alpha$ ) present in a subset of microglia that were closely associated with retinal vessels. These findings suggested the possibility that omega-3 fatty acid supplementation to premature infants may be of benefit in preventing ROP. In this regard, a recent meta-analysis showed that LCPUFA supplementation of infant formulas improves infants' visual acuity up to 12 months of age [180]. However, the impact of fortification of infant formula or breast-feeding mothers supplemented with omega-3 fatty acids to treat ROP needs further study. Currently, the University of California is conducting a trial to supplement very low birth weight infants with omega-3 PUFAs for the prevention of ROP (NCT02486042).

\section{Future therapies}

Stem cell therapy

Stem cells provide an attractive therapeutic approach in treating ischemic retinopathies including ROP, due to its potential in tissue regeneration. Several groups have shown that different populations of stem cells could promote vascular repair in OIR model [181-183]. For instance, myeloid progenitors were able to migrate to the retinal avascular areas, differentiate into microglia, and participate in the reduction of vasoobliteration and neovascularization in OIR-transplanted animals [181]. Furthermore, bone marrow-derived stem cells targeted retinal astrocytes and promoted or inhibited retinal angiogenesis [182]. Another candidate in cell-based therapy for ROP is endothelial progenitor cells (EPCs) [184]. Interestingly, EPCs derived from human peripheral blood

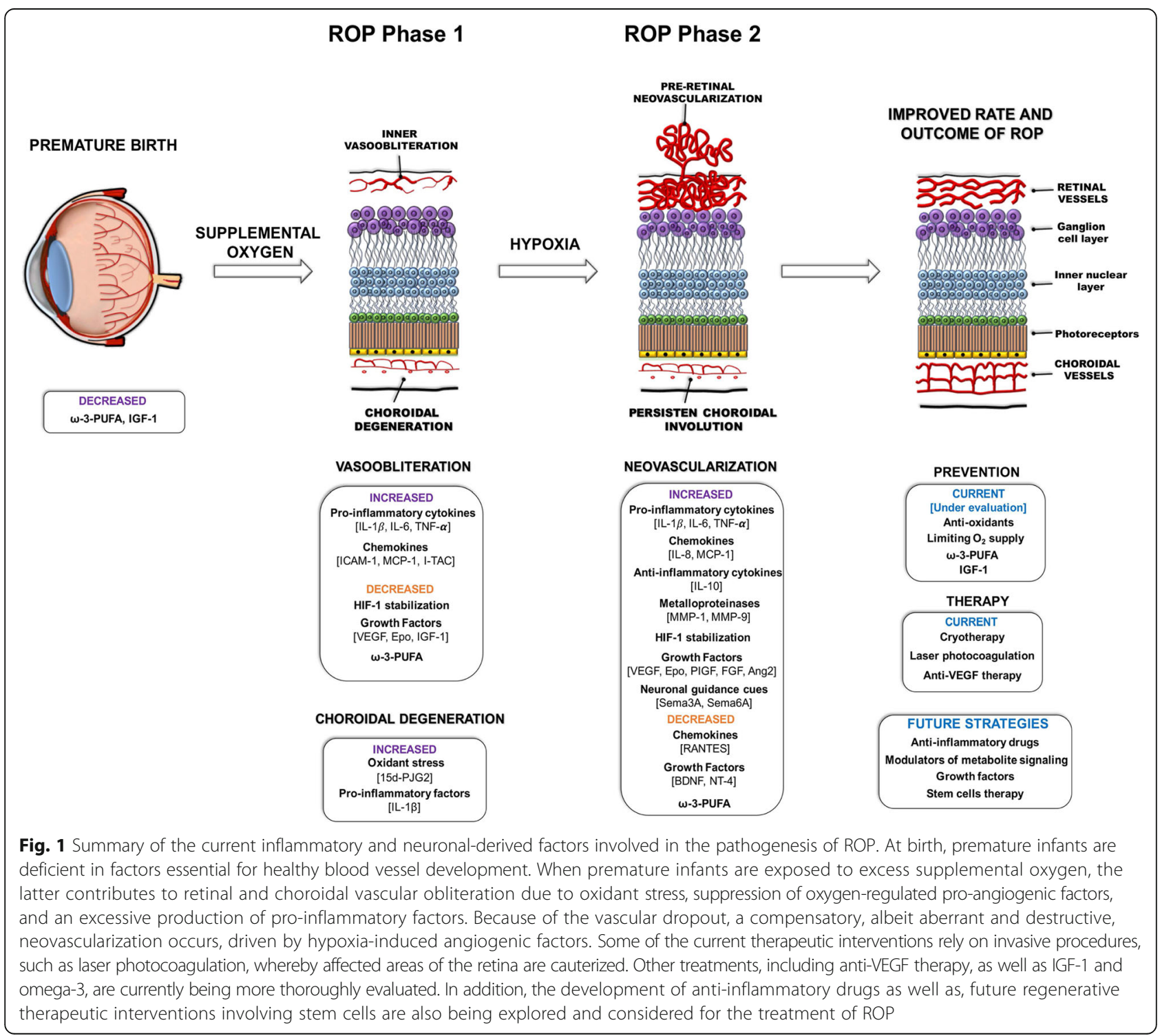


(injected intravitreally) were found to incorporate in the resident vasculature and promote tube formationessential for vascular remodeling in ischemic regions [185]. However, the benefits of EPCs remain controversial since they have also been shown to contribute to pathological neovascularization in humans $[186,187]$.

\section{Gene therapy}

Gene therapy may be a possible treatment option for patients with ROP. Viral vectors can be used to transport therapeutic material to cells of the retina [188]. Adenovirus (Ad), adeno-associated virus (AAV), and lentivirus are most commonly used for retinal transgene delivery [189]. In this regard, a recent study showed that sub-retinal injection of an AAV carrying any of a variety of antiangiogenic genes including endostatin, pigment epithelium-derived factor (PEDF), and tissue inhibitor of metalloproteinases 3 (TIMP3) was able to significantly inhibit pathological neovascularization in the ROP model [190]. Thus, gene therapy-mediated regulation of cytokines and growth factors involved in ROP is a potential albeit at present farfetching approach in premature babies.

\section{Conclusion}

The search for biomarkers to identify children at risk of vision-threatening ROP has led to identification of several promising indicators related to inflammation and angiogenesis. Although many of the harmful effects of pre- and postnatal inflammation are known, there is a lack of validated markers that can help identify children at-risk of ROP. The two-phase development of ROP underscores the importance of assessing biomarker concentrations over time when studying ROP pathogenesis, since a specific biomarker can exert opposing outcomes depending on the disease phase. Less destructive tissuepreserving therapies (than current laser ablation) are being explored, and include IGF-1, PUFAs, and potentially stem cell therapy, as well as, modulation of factors involved in neuronal guidance of vasculature and inflammation. In the overall context of ROP, the role of choroid degeneration in ROP also needs to be accounted for (Fig. 1). Although it is clear that a large body of our knowledge on the molecular aspects of the pathogenesis of ROP stems from animal models with OIR, yet OIR does not fully reflect the complex human condition of ROP. This emphasizes the added importance of epidemiological studies with an unbiased molecular dimension.

\footnotetext{
Abbreviations

15d-PGJ2: Electrophile 15-deoxy-12,14-PGJ2; AAV: Adeno-associated virus; Ad: Adenovirus; Ang1: Angiopoietins 1; BDNF: Brain-derived neurotrophic factor; bFGF: Asic fibroblast growth factor; DHA: Docosahexaenoic acid; EPO: Erythropoietin; IGF-1: Insulin-like growth factor-1; I-TAC: Interferoninducible T-cell a chemoattractant; MCP1: Monocyte chemotactic protein 1; MMP: Matrix Metalloproteinase; Nrf2: Transcription factor NF-E2-related factor 2; NT-4: Neurotropin 4; OIR: Oxygen-induced retinopathy;
}

PGD2: Prostaglandin D2:; PIGF: Placental growth factor; PR: Photoreceptors; PUFAs: Polyunsaturated fatty acids; ROP: Retinopathy of prematurity; ROS: Reactive oxygen species; RPE: Retinal pigment epithelium; Sema3A: Semaphorin 3A; Sema3E: Semaphorin3E; shRNA: Small hairpin RNA; TIMP3: Tissue inhibitor of metalloproteinases 3; TSH: Thyroid-stimulating hormone; VEGF: Vascular endothelial growth factor; WINROP: Weight, insulinlike growth factor I, neonatal, retinopathy of prematurity

\section{Acknowledgements}

Not applicable.

\section{Funding}

SC holds a Canada Research Chair (Translational Research in Vision) and the Leopoldine Wolfe Chair in translational research in age-related macular degeneration. Work related to ROP has been supported by Canadian Institutes of Health Research (SC), March of Dimes (SC), and National Institutes of Health (OD).

\section{Availability of data and materials \\ Not applicable.}

\section{Authors' contributions}

$J C R$ and $\mathrm{MH}$ are the major contributors in written the manuscript. DA, TSM TEZ, ABR, and EMS corrected and gave suggestions to the manuscript. JCR designed the drawing for the manuscript. OD and SC provided expert advice and gave important suggestions for improving the manuscript. All authors read and approved the final manuscript.

Ethics approval and consent to participate Not applicable.

Consent for publication

Not applicable.

\section{Competing interests}

The corresponding author (SC) holds a patent on a small peptide antagonist of IL-1 receptor, which could be useful in inflammatory ischemic retinopathies; yet, this compound remains at pre-clinical stage and the intellectual property is held by the $\mathrm{CHU}$ Ste. Justine, Montreal. Hence the competing interests are at best questionable.

\section{Publisher's Note}

Springer Nature remains neutral with regard to jurisdictional claims in published maps and institutional affiliations.

\section{Author details}

${ }^{1}$ Department of Pediatrics, Ophthalmology and Pharmacology, Centre Hospitalier Universitaire Sainte-Justine Research Center, 3175, Chemin Côte Ste-Catherine, Montréal, Québec, Canada. ${ }^{2}$ Department of Ophthalmology, Maisonneuve-Rosemont Hospital Research Center, University of Montréal, Montréal, Québec, Canada. 'Department of Laboratory Medicine, Children's and Women's Health, Norwegian University of Science and Technology (NTNU), Trondheim, Norway. ${ }^{4}$ Department of Ophthalmology, Trondheim University Hospital, Trondheim, Norway. ${ }^{5}$ Department of Neuromedicine and Movement Science, Norwegian University of Science and Technology (NTNU), Trondheim, Norway. ${ }^{6}$ Departament of Public Health Community Medicine, Tufts University School of Medicine, Boston, MA, USA. ${ }^{7}$ Perinatal Neuroepidemiology Unit, Hannover Medical School, Hannover, Germany.

Received: 25 February 2017 Accepted: 14 August 2017

Published online: 22 August 2017

\section{References}

1. Good W, Hardy RJ, Dobson V, Palmer EA, Phelps DL, Quintos M, Tung B. The incidence and course of retinopathy of prematurity: findings from the early treatment for retinopathy of prematurity study. Pediatrics. 2005:116:15-23.

2. Zin A, Gole GA. Retinopathy of prematurity-incidence today. Clin Perinatol. 2013:40:185-200

3. Blencowe H, Lawn JE, Vazquez T, Fielder A, Gilbert C. Preterm-associated visual impairment and estimates of retinopathy of prematurity at regional and global levels for 2010. Pediatr Res. 2013;74(Suppl 1):35-49. 
4. Gilbert C, Fielder A, Gordillo L, Quinn G, Semiglia R, Visintin P, Zin A, International NOROPG. Characteristics of infants with severe retinopathy of prematurity in countries with low, moderate, and high levels of development: implications for screening programs. Pediatrics. 2005;115:e518-25.

5. Austeng D, Kallen KB, Ewald UW, Jakobsson PG, Holmstrom GE. Incidence of retinopathy of prematurity in infants born before 27 weeks' gestation in Sweden. Arch Ophthalmol. 2009;127:1315-9.

6. Garner A, Ashton N. Vaso-obliteration and retrolental fibroplasia. Proc R Soc Med. 1971:64:774-7.

7. Kushner BJ, Essner D, Cohen IJ, Flynn JT. Retrolental fibroplasia. II. Pathologic correlation. Arch Ophthalmol. 1977;95:29-38.

8. Rivera JC, Sapieha P, Joyal JS, Duhamel F, Shao Z, Sitaras N, Picard E, Zhou E, Lachapelle P, Chemtob S. Understanding retinopathy of prematurity: update on pathogenesis. Neonatology. 2011;100:343-53.

9. Rivera JC, Madaan A, Zhou TE, Chemtob S. Review of the mechanisms and therapeutic avenues for retinal and choroidal vascular dysfunctions in retinopathy of prematurity. Acta Paediatr. 2016;105:1421-33.

10. McColm JR, Fleck BW. Retinopathy of prematurity: causation. Semin Neonatol. 2001;6:453-60.

11. Seiberth $\mathrm{V}$, Linderkamp $\mathrm{O}$. Risk factors in retinopathy of prematurity. a multivariate statistical analysis. Ophthalmologica. 2000;214:131-5.

12. Lofavist C, Engstrom E, Sigurdsson J, Hard AL, Niklasson A, Ewald U, Holmstrom G, Smith LE, Hellstrom A. Postnatal head growth deficit among premature infants parallels retinopathy of prematurity and insulin-like growth factor-1 deficit. Pediatrics. 2006;117:1930-8.

13. Sato T, Kusaka S, Shimojo H, Fujikado T. Simultaneous analyses of vitreous levels of 27 cytokines in eyes with retinopathy of prematurity. Ophthalmology. 2009;116:2165-9.

14. Sood BG, Madan A, Saha S, Schendel D, Thorsen P, Skogstrand K, Hougaard D, Shankaran S, Carlo W. Perinatal systemic inflammatory response syndrome and retinopathy of prematurity. Pediatr Res. 2010;67:394-400.

15. Checchin D, Sennlaub F, Levavasseur E, Leduc M, Chemtob S. Potential role of microglia in retinal blood vessel formation. Invest Ophthalmol Vis Sci. 2006:47:3595-602.

16. Ishida S, Yamashiro K, Usui T, Kaji Y, Ogura Y, Hida T, Honda Y, Oguchi Y, Adamis AP. Leukocytes mediate retinal vascular remodeling during development and vaso-obliteration in disease. Nat Med. 2003;9:781-8.

17. Lee J, Dammann O. Perinatal infection, inflammation, and retinopathy of prematurity. Semin Fetal Neonatal Med. 2012;17:26-9.

18. Holmstrom G, Broberger U, Thomassen P. Neonatal risk factors for retinopathy of prematurity—a population-based study. Acta Ophthalmol Scand. 1998;76:204-7.

19. Klinger G, Levy I, Sirota L, Boyko V, Lerner-Geva L, Reichman B. Outcome of early-onset sepsis in a national cohort of very low birth weight infants. Pediatrics. 2010;125:e736-40

20. Chen ML, Allred EN, Hecht JL, Onderdonk A, Vanderveen D, Wallace D, Leviton A, Dammann O, Investigators. ftES. Placenta microbiology and histology and the risk for severe retinopathy of prematurity. Invest Ophthalmol Vis Sci. 2011;52:7052-8.

21. Tolsma KW, Allred EN, Chen ML, Duker J, Leviton A, Dammann O, Investigators. $\mathrm{ftES}$. Neonatal Bacteremia and retinopathy of prematurity: the ELGAN study. Arch Ophthalmol. 2011;129:1555-63.

22. Tremblay S, Miloudi K, Chaychi S, Favret S, Binet F, Polosa A, Lachapelle P, Chemtob S, Sapieha P. Systemic inflammation perturbs developmental retinal angiogenesis and neuroretinal function. Invest Ophthalmol Vis Sci. 2013;54:8125-39.

23. Hong HK, Lee HJ, Ko JH, Park JH, Park JY, Choi CW, Yoon CH, Ahn SJ, Park KH, Woo SJ, Oh JY. Neonatal systemic inflammation in rats alters retinal vessel development and simulates pathologic features of retinopathy of prematurity. J Neuroinflammation. 2014;11:87

24. Ribatti D, Crivellato E. Immune cells and angiogenesis. J Cell Mol Med. 2009:13:2822-33.

25. Szade A, Grochot-Przeczek A, Florczyk U, Jozkowicz A, Dulak J. Cellular and molecular mechanisms of inflammation-induced angiogenesis. IUBMB Life. 2015:67:145-59.

26. Msall ME. The retina as a window to the brain in vulnerable neonates. Pediatrics. 2006;117:2287-9.

27. Fischer F, Martin G, Agostini HT. Activation of retinal microglia rather than microglial cell density correlates with retinal neovascularization in the mouse model of oxygen-induced retinopathy. J Neuroinflammation. 2011;8:120.

28. Wollen EJ, Sejersted Y, Wright MS, Madetko-Talowska A, Bik-Multanowski M, Kwinta P, Gunther CC, Nygard S, Loberg EM, Ystgaard MB, et al. Transcriptome profiling of the newborn mouse brain after hypoxia-reoxygenation: hyperoxic reoxygenation induces inflammatory and energy failure responsive genes. Pediatr Res. 2014;75:517-26.

29. Allred EN, Capone A Jr, Fraioli A, Dammann O, Droste P, Duker J, Gise R, Kuban K, Leviton A, O'Shea TM, et al. Retinopathy of prematurity and brain damage in the very preterm newborn. J AAPOS. 2014;18:241-7.

30. Schmidt B, Davis PG, Asztalos EV, Solimano A, Roberts RS. Association between severe retinopathy of prematurity and nonvisual disabilities at age 5 years. JAMA. 2014;311:523-5.

31. Msall ME, Phelps DL, DiGaudio KM, Dobson V, Tung B, McClead RE, Quinn GE, Reynolds JD, Hardy RJ, Palmer EA. Severity of neonatal retinopathy of prematurity is predictive of neurodevelopmental functional outcome at age 5.5 years. Behalf of the Cryotherapy for retinopathy of prematurity cooperative group. Pediatrics. 2000;106:998-1005

32. Msall ME, Phelps DL, Hardy RJ, Dobson V, Quinn GE, Summers CG, Tremont MR. Educational and social competencies at 8 years in children with threshold retinopathy of prematurity in the CRYO-ROP multicenter study. Pediatrics. 2004;113:790-9.

33. Quinn GE, Dobson V, Saigal S, Phelps DL, Hardy RJ, Tung B, Summers CG, Palmer EA. Health-related quality of life at age 10 years in very low-birthweight children with and without threshold retinopathy of prematurity. Arch Ophthalmol. 2004;122:1659-66.

34. Blencowe H, Lee AC, Cousens S, Bahalim A, Narwal R, Zhong N, Chou D, Say L, Modi N, Katz J, et al. Preterm birth-associated neurodevelopmental impairment estimates at regional and global levels for 2010. Pediatr Res. 2013;74(Suppl 1):17-34.

35. Shao Z, Dorfman AL, Seshadri S, Djavari M, Kermorvant-Duchemin E, Sennlaub F, Blais M, Polosa A, Varma DR, Joyal JS, et al. Choroidal involution is a key component of oxygen-induced retinopathy. Invest Ophthalmol Vis Sci. 2011;52:6238-48

36. Fulton $\mathrm{AB}$, Hansen RM, Moskowitz A, Akula JD. The neurovascular retina in retinopathy of prematurity. Prog Retin Eye Res. 2009;28:452-82.

37. Malaeb S, Dammann O. Fetal inflammatory response and brain injury in the preterm newborn. J Child Neurol. 2009:24:1119-26.

38. Dammann O, O'Shea TM. Cytokines and perinatal brain damage. Clin Perinatol. 2008:35:643-63. v

39. Fichorova RN, Beatty N, Sassi RR, Yamamoto HS, Allred EN, Leviton A. Systemic inflammation in the extremely low gestational age newborn following maternal genitourinary infections. Am J Reprod Immunol. 2015;73:162-74.

40. Gabay C, Kushner I. Acute-phase proteins and other systemic responses to inflammation. N Engl J Med. 1999;340:448-54.

41. Opal SM, DePalo VA. Anti-inflammatory cytokines. Chest. 2000;117:1162-72.

42. Charo IF, Ransohoff RM. The many roles of chemokines and chemokine receptors in inflammation. N Engl J Med. 2006;354:610-21.

43. Sivakumar V, Foulds WS, Luu CD, Ling EA, Kaur C. Retinal ganglion cell death is induced by microglia derived pro-inflammatory cytokines in the hypoxic neonatal retina. J Pathol. 2011;224:245-60.

44. Rivera JC, Sitaras N, Noueihed B, Hamel D, Madaan A, Zhou T, Honore JC, Quiniou C, Joyal JS, Hardy P, et al. Microglia and interleukin-1 beta in ischemic retinopathy elicit microvascular degeneration through neuronal semaphorin-3A. Arterioscler Thromb Vasc Biol. 2013;33:1881-91.

45. Zhou TE, Rivera JC, Bhosle VK, Lahaie I, Shao Z, Tahiri H, Zhu T, Polosa A, Dorfman A, Beaudry-Richard A, et al. Choroidal involution is associated with a progressive degeneration of the outer retinal function in a model of retinopathy of prematurity: early role for IL-1 beta. Am J Pathol. 2016;186:3100-16.

46. Dace DS, Khan AA, Kelly J, Apte RS. Interleukin-10 promotes pathological angiogenesis by regulating macrophage response to hypoxia during development. PLoS One. 2008;3:e3381.

47. Kremlev SG, Palmer C. Interleukin-10 inhibits endotoxin-induced pro-inflammatory cytokines in microglial cell cultures. J Neuroimmunol. 2005;162:71-80.

48. Rodts-Palenik S, Wyatt-Ashmead J, Pang Y, Thigpen B, Cai Z, Rhodes P, Martin JN, Granger J, Bennett WA. Maternal infection-induced white matter injury is reduced by treatment with interleukin-10. Am J Obstet Gynecol. 2004;191:1387-92.

49. Dordelmann M, Kerk J, Dressler F, Brinkhaus MJ, Bartels DB, Dammann CE, Dork T, Dammann O. Interleukin-10 high producer allele and ultrasounddefined periventricular white matter abnormalities in preterm infants: a preliminary study. Neuropediatrics. 2006;37:130-6.

50. Woo SJ, Park KH, Lee SY, Ahn SJ, Ahn J, Park KH, Oh KJ, Ryu A. The relationship between cord blood cytokine levels and perinatal factors and 
retinopathy of prematurity: a gestational age-matched case-control study. Invest Ophthalmol Vis Sci. 2013;54:3434-9.

51. Chernykh W, Varvarinsky EV, Smirnov EV, Chernykh DV, Trunov AN. Proliferative and inflammatory factors in the vitreous of patients with proliferative diabetic retinopathy. Indian J Ophthalmol. 2015;63:33-6.

52. Ghasemi H, Ghazanfari T, Yaraee R, Faghihzadeh S, Hassan ZM. Roles of IL-8 in ocular inflammations: a review. Ocul Immunol Inflamm. 2011;19:401-12.

53. Silveira RC, Fortes Filho JB, Procianoy RS. Assessment of the contribution of cytokine plasma levels to detect retinopathy of prematurity in very low birth weight infants. Invest Ophthalmol Vis Sci. 2011;52:1297-301.

54. Powers MR, Davies MH, Eubanks JP. Increased expression of chemokine KC, an interleukin-8 homologue, in a model of oxygen-induced retinopathy. Curr Eye Res. 2005;30:299-307.

55. Hellgren G, Willett K, Engstrom E, Thorsen P, Hougaard DM, Jacobsson B, Hellstrom A, Lofqvist C. Proliferative retinopathy is associated with impaired increase in BDNF and RANTES expression levels after preterm birth. Neonatology. 2010;98:409-18.

56. Yao Y, Tsirka SE. Monocyte chemoattractant protein-1 and the blood-brain barrier. Cell Mol Life Sci. 2014;71:683-97.

57. Yu H, Yuan L, Zou Y, Peng L, Wang Y, Li T, Tang S. Serum concentrations of cytokines in infants with retinopathy of prematurity. APMIS. 2014;122:818-23.

58. Natarajan G, Shankaran S, McDonald SA, Das A, Stoll BJ, Higgins RD, Thorsen P, Skogstrand K, Hougaard DM, Carlo WA. Circulating beta chemokine and MMP 9 as markers of oxidative injury in extremely low birth weight infants. Pediatr Res. 2010;67:77-82.

59. Yoshimura T, Sonoda KH, Sugahara M, Mochizuki Y, Enaida H, Oshima Y, Ueno A, Hata Y, Yoshida H, Ishibashi T. Comprehensive analysis of inflammatory immune mediators in vitreoretinal diseases. PLoS One. 2009:4:e8158.

60. Rusnak S, Vrzalova J, Sobotova M, Hecova L, Ricarova R, Topolcan O. The measurement of intraocular biomarkers in various stages of proliferative diabetic retinopathy using multiplex xMAP technology. J Ophthalmol. 2015;2015:424783.

61. Yoshida S, Yoshida A, Ishibashi T, Elner SG, Elner VM. Role of MCP-1 and MIP-1alpha in retinal neovascularization during postischemic inflammation in a mouse model of retinal neovascularization. J Leukoc Biol. 2003;73:137-44.

62. Yoshida S, Yoshida A, Ishibashi T. Induction of IL-8, MCP-1, and bFGF by TNFalpha in retinal glial cells: implications for retinal neovascularization during postischemic inflammation. Graefes Arch Clin Exp Ophthalmol. 2004;242:409-13.

63. Hennigan A, O'Callaghan RM, Kelly AM. Neurotrophins and their receptors: roles in plasticity, neurodegeneration and neuroprotection. Biochem Soc Trans. 2007;35:424-7

64. Hartnett ME, Morrison MA, Smith S, Yanovitch TL, Young TL, Colaizy T, Momany A, Dagle J, Carlo WA, Clark EA, et al. Genetic variants associated with severe retinopathy of prematurity in extremely low birth weight infants. Invest Ophthalmol Vis Sci. 2014;55:6194-203.

65. Rao R, Mashburn CB, Mao J, Wadhwa N, Smith GM, Desai NS. Brain-derived neurotrophic factor in infants $<32$ weeks gestational age: correlation with antenatal factors and postnatal outcomes. Pediatr Res. 2009;65:548-52.

66. Qazi Y, Maddula S, Ambati BK. Mediators of ocular angiogenesis. J Genet. 2009;88:495-515.

67. Cockle JV, Gopichandran N, Walker JJ, Levene MI, Orsi NM. Matrix metalloproteinases and their tissue inhibitors in preterm perinatal complications. Reprod Sci. 2007;14:629-45.

68. Schulz CG, Sawicki G, Lemke RP, Roeten BM, Schulz R, Cheung PY. MMP-2 and MMP-9 and their tissue inhibitors in the plasma of preterm and term neonates. Pediatr Res. 2004;55:794-801.

69. Das A, McLamore A, Song W, McGuire PG. Retinal neovascularization is suppressed with a matrix metalloproteinase inhibitor. Arch Ophthalmol. 1999;117:498-503.

70. Arjamaa O, Nikinmaa M. Oxygen-dependent diseases in the retina: role of hypoxia-inducible factors. Exp Eye Res. 2006;83:473-83.

71. Huang $H$, Van de Veire S, Dalal M, Parlier R, Semba RD, Carmeliet $P$, Vinores SA. Reduced retinal neovascularization, vascular permeability, and apoptosis in ischemic retinopathy in the absence of prolyl hydroxylase-1 due to the prevention of hyperoxia-induced vascular obliteration. Invest Ophthalmol Vis Sci. 2011;52:7565-73

72. Kim JH, Kim JH, Yu YS, Shin JY, Lee HY, Kim KW. Dequelin inhibits retinal neovascularization by down-regulation of HIF-1alpha in oxygen-induced retinopathy. J Cell Mol Med. 2008;12:2407-15.

73. Sato T, Kusaka S, Shimojo H, Fujikado T. Vitreous levels of erythropoietin and vascular endothelial growth factor in eyes with retinopathy of prematurity. Ophthalmology. 2009;116:1599-603.
74. Sonmez K, Drenser KA, Capone A Jr, Trese MT. Vitreous levels of stromal cell-derived factor 1 and vascular endothelial growth factor in patients with retinopathy of prematurity. Ophthalmology. 2008;115:1065-70. e1061

75. Klufas MA, Chan RV. Intravitreal anti-VEGF therapy as a treatment for retinopathy of prematurity: what we know after 7 years. J Pediatr Ophthalmol Strabismus. 2015;52:77-84.

76. Ramakrishnan S, Anand V, Roy S. Vascular endothelial growth factor signaling in hypoxia and inflammation. J Neurolmmune Pharmacol. 2014;9:142-60.

77. Rahimi N. Vascular endothelial growth factor receptors: molecular mechanisms of activation and therapeutic potentials. Exp Eye Res. 2006;83:1005-16.

78. Pieh C, Agostini H, Buschbeck C, Kruger M, Schulte-Monting J, Zirrgiebel U, Drevs J, Lagreze WA. VEGF-A, VEGFR-1, VEGFR-2 and Tie2 levels in plasma of premature infants: relationship to retinopathy of prematurity. $\mathrm{Br} J$ Ophthalmol. 2008;92:689-93.

79. Wilkinson-Berka JL, Babic S, De Gooyer T, Stitt AW, Jaworski K, Ong LG, Kelly DJ, Gilbert RE. Inhibition of platelet-derived growth factor promotes pericyte loss and angiogenesis in ischemic retinopathy. Am J Pathol. 2004;164:1263-73.

80. Budd S, Byfield G, Martiniuk D, Geisen P, Hartnett ME. Reduction in endothelial tip cell filopodia corresponds to reduced intravitreous but not intraretinal vascularization in a model of ROP. Exp Eye Res. 2009;89:718-27.

81. Jelkmann W. Erythropoietin after a century of research: younger than ever. Eur J Haematol. 2007;78:183-205.

82. Arcasoy MO. Non-erythroid effects of erythropoietin. Haematologica. 2010;95:1803-5

83. Juul SE, Joyce $A E$, Zhao $Y$, Ledbetter DJ. Why is erythropoietin present in human milk? Studies of erythropoietin receptors on enterocytes of human and rat neonates. Pediatr Res. 1999;46:263-8.

84. Ohlsson A, Aher SM. Early erythropoietin for preventing red blood cell transfusion in preterm and/or low birth weight infants. Cochrane Database Syst Rev. 2014;4:CD004863.

85. Leuchter RH, Gui L, Poncet A, Hagmann C, Lodygensky GA, Martin E, Koller B, Darque A, Bucher HU, Huppi PS. Association between early administration of high-dose erythropoietin in preterm infants and brain MRI abnormality at term-equivalent age. JAMA. 2014;312:817-24.

86. Neubauer AP, Voss W, Wachtendorf M, Jungmann T. Erythropoietin improves neurodevelopmental outcome of extremely preterm infants. Ann Neurol. 2010;67:657-66.

87. Messier AM, Ohls RK. Neuroprotective effects of erythropoiesis-stimulating agents in term and preterm neonates. Curr Opin Pediatr. 2014;26:139-45.

88. Juul S. Neuroprotective role of erythropoietin in neonates. J Matern Fetal Neonatal Med. 2012;25(Suppl 4):105-7.

89. Wells Logan J, Allred EN, Fichorova RN, Engelke S, Dammann O, Leviton A. Endogenous erythropoietin varies significantly with inflammation-related proteins in extremely premature newborns. Cytokine. 2014;69:22-8.

90. Holm M, Skranes J, Dammann O, Fichorova RN, Allred EN, Leviton A Systemic endogenous erythropoietin and associated disorders in extremely preterm newborns. Arch Dis Child Fetal Neonatal Ed. 2016;101(5):F458-63.

91. Chen M, Citil A, McCabe F, Leicht KM, Fiascone J, Dammann CE, Dammann O. Infection, oxygen, and immaturity: interacting risk factors for retinopathy of prematurity. Neonatology. 2011;99:125-32.

92. Chen J, Connor KM, Aderman CM, Smith LE. Erythropoietin deficiency decreases vascular stability in mice. J Clin Invest. 2008;118:526-33.

93. Hellstrom A, Carlsson B, Niklasson A, Segnestam K, Boguszewski M, de Lacerda $L$, Savage M, Svensson E, Smith L, Weinberger D, et al. IGF-I is critical for normal vascularization of the human retina. J Clin Endocrinol Metab. 2002;87:3413-6.

94. Hellstrom A, Perruzzi C, Ju M, Engstrom E, Hard AL, Liu JL, Albertsson-Wikland K, Carlsson B, Niklasson A, Sjodell L, et al. Low IGF-I suppresses VEGF-survival signaling in retinal endothelial cells: direct correlation with clinical retinopathy of prematurity. Proc Natl Acad Sci U S A. 2001;98:5804-8.

95. Smith LE, Shen W, Perruzzi C, Soker S, Kinose F, Xu X, Robinson G, Driver S, Bischoff J, Zhang B, et al. Regulation of vascular endothelial growth factordependent retinal neovascularization by insulin-like growth factor-1 receptor. Nat Med. 1999;5:1390-5.

96. Piecewicz SM, Pandey A, Roy B, Xiang SH, Zetter BR, Sengupta S. Insulin-like growth factors promote vasculogenesis in embryonic stem cells. PLoS One. 2012;7(2):e32191.

97. Hansen-Pupp I, Hellstrom-Westas L, Cilio CM, Andersson S, Fellman V, Ley D. Inflammation at birth and the insulin-like growth factor system in very preterm infants. Acta Paediatr. 2007;96:830-6.

98. Hellstrom A, Engstrom E, Hard AL, Albertsson-Wikland K, Carlsson B, Niklasson A, Lofqvist C, Svensson E, Holm S, Ewald U, et al. Postnatal 
serum insulin-like growth factor I deficiency is associated with retinopathy of prematurity and other complications of premature birth. Pediatrics. 2003;112:1016-20.

99. Zhou AY, Bai YJ, Zhao M, Yu WZ, Huang LZ, Li XX. Placental growth factor expression is reversed by antivascular endothelial growth factor therapy under hypoxic conditions. World J Pediatr. 2014;10:262-70.

100. Autiero M, Luttun A, Tjwa M, Carmeliet P. Placental growth factor and its receptor, vascular endothelial growth factor receptor-1: novel targets for stimulation of ischemic tissue revascularization and inhibition of angiogenic and inflammatory disorders. J Thromb Haemost. 2003;1:1356-70.

101. Simpson DA, Murphy GM, Bhaduri T, Gardiner TA, Archer DB, Stitt AW. Expression of the VEGF gene family during retinal vaso-obliteration and hypoxia. Biochem Biophys Res Commun. 1999;262:333-40.

102. Luttun A, Brusselmans K, Fukao H, Tjwa M, Ueshima S, Herbert JM, Matsuo O, Collen D, Carmeliet P, Moons L. Loss of placental growth factor protects mice against vascular permeability in pathological conditions. Biochem Biophys Res Commun. 2002;295:428-34

103. Javerzat $S$, Auguste $P$, Bikfalvi A. The role of fibroblast growth factors in vascular development. Trends Mol Med. 2002;8:483-9.

104. Rousseau B, Larrieu-Lahargue F, Bikfalvi A, Javerzat S. Involvement of fibroblast growth factors in choroidal angiogenesis and retinal vascularization. Exp Eye Res. 2003;77:147-56.

105. Xiang N, Zhao MJ, Li XY, Zheng HH, Li GG, Li B. Redundant mechanisms for vascular growth factors in retinopathy of prematurity in vitro. Ophthalmic Res. 2011;45:92-101.

106. Fang L, Barber AJ, Shenberger JS. Regulation of fibroblast growth factor 2 expression in oxygen-induced retinopathy. Invest Ophthalmol Vis Sci. 2015:56:207-15

107. Yamada H, Yamada E, Ando A, Esumi N, Bora N, Saikia J, Sung CH, Zack DJ, Campochiaro PA. Fibroblast growth factor-2 decreases hyperoxia-induced photoreceptor cell death in mice. Am J Pathol. 2001;159:1113-20.

108. Joly S, Pernet V, Chemtob S, Di Polo A, Lachapelle P. Neuroprotection in the juvenile rat model of light-induced retinopathy: evidence suggesting a role for FGF-2 and CNTF. Invest Ophthalmol Vis Sci. 2007:48:2311-20.

109. Ozaki H, Okamoto N, Ortega S, Chang M, Ozaki K, Sadda S, Vinores MA, Derevjanik N, Zack DJ, Basilico C, Campochiaro PA. Basic fibroblast growth factor is neither necessary nor sufficient for the development of retinal neovascularization. Am J Pathol. 1998;153:757-65.

110. Takagi H, Koyama S, Seike H, Oh H, Otani A, Matsumura M, Honda Y. Potential role of the angiopoietin/tie2 system in ischemia-induced retinal neovascularization. Invest Ophthalmol Vis Sci. 2003;44:393-402.

111. Asahara T, Chen D, Takahashi T, Fujikawa K, Kearney M, Magner M, Yancopoulos GD, Isner JM. Tie2 receptor ligands, angiopoietin-1 and angiopoietin-2, modulate VEGF-induced postnatal neovascularization. Circ Res. 1998;83:233-40

112. Sato T, Shima C, Kusaka S. Vitreous levels of angiopoietin-1 and angiopoietin-2 in eyes with retinopathy of prematurity. Am J Ophthalmol. 2011:151:353-7. e351

113. Patel J, Landers K, Li H, Mortimer RH, Richard K. Thyroid hormones and fetal neurological development. J Endocrinol. 2011;209:1-8.

114. Sevilla-Romero E, Munoz A, Pinazo-Duran MD. Low thyroid hormone levels impair the perinatal development of the rat retina. Ophthalmic Res. 2002;34:181-91.

115. Simic N, Asztalos EV, Rovet J. Impact of neonatal thyroid hormone insufficiency and medical morbidity on infant neurodevelopment and attention following preterm birth. Thyroid. 2009:19:395-401.

116. Scratch SE, Hunt RW, Thompson DK, Ahmadzai ZM, Doyle LW, Inder TE, Anderson PJ. Free thyroxine levels after very preterm birth and neurodevelopmental outcomes at age 7 years. Pediatrics. 2014;133:e955-63.

117. Osborn DA, Hunt RW. Prophylactic postnatal thyroid hormones for prevention of morbidity and mortality in preterm infants. Cochrane Database Syst Rev. 2007;(1):CD005948.

118. Korzeniewski SJ, Soto-Rivera CL, Fichorova RN, Allred EN, Kuban KC, O'Shea TM, Paneth N, Agus M, Dammann O, Leviton A. Are preterm newborns who have relative hyperthyrotropinemia at increased risk of brain damage? J Pediatr Endocrinol Metab. 2014;27:1077-88.

119. Soto-Rivera CL, Fichorova RN, Allred EN, Van Marter LJ, Shah B, Martin CR, Agus MS, Leviton A. The relationship between TSH and systemic inflammation in extremely preterm newborns. Endocrine. 2015:48:595-602.

120. Joyal JS, Sitaras N, Binet F, Rivera JC, Stahl A, Zaniolo K, Shao Z, Polosa A, Zhu T, Hamel D, et al. Ischemic neurons prevent vascular regeneration of neural tissue by secreting semaphorin 3A. Blood. 2011;117:6024-35.
121. Segarra M, Ohnuki H, Maric D, Salvucci O, Hou X, Kumar A, Li X, Tosato G. Semaphorin $6 \mathrm{~A}$ regulates angiogenesis by modulating VEGF signaling. Blood. 2012;120:4104-15.

122. Guttmann-Raviv N, Shraga-Heled N, Varshavsky A, Guimaraes-Sternberg C, Kessler O, Neufeld G. Semaphorin-3A and semaphorin-3F work together to repel endothelial cells and to inhibit their survival by induction of apoptosis. J Biol Chem. 2007;282:26294-305.

123. Wei Y, Gong J, Xu Z, Thimmulappa RK, Mitchell KL, Welsbie DS, Biswal S, Duh EJ. $\mathrm{Nrf2}$ in ischemic neurons promotes retinal vascular regeneration through regulation of semaphorin 6A. Proc Natl Acad Sci U S A. 2015;112:E6927-36.

124. Fukushima Y, Okada M, Kataoka H, Hirashima M, Yoshida Y, Mann F, Gomi F, Nishida K, Nishikawa S, Uemura A. Sema3E-PlexinD1 signaling selectively suppresses disoriented angiogenesis in ischemic retinopathy in mice. J Clin Invest. 2011;121:1974-85

125. Yang WJ, Hu J, Uemura A, Tetzlaff F, Augustin HG, Fischer A. Semaphorin-3C signals through Neuropilin-1 and PlexinD1 receptors to inhibit pathological angiogenesis. EMBO Mol Med. 2015;7:1267-84.

126. Harris ME, Moskowitz A, Fulton AB, Hansen RM. Long-term effects of retinopathy of prematurity (ROP) on rod and rod-driven function. Doc Ophthalmol. 2011;122:19-27.

127. Hansen RM, Moskowitz A, Tavormina JL, Bush JN, Soni G, Fulton AB Temporal summation in children with a history of retinopathy of prematurity. Invest Ophthalmol Vis Sci. 2015;56:914-7.

128. Bosworth RG, Robbins SL, Granet DB, Dobkins KR. Delayed luminance and chromatic contrast sensitivity in infants with spontaneously regressed retinopathy of prematurity. Doc Ophthalmol. 2013;127:57-68.

129. Siatkowski RM, Dobson V, Quinn GE, Summers CG, Palmer EA, Tung B. Severe visual impairment in children with mild or moderate retinal residua following regressed threshold retinopathy of prematurity. J AAPOS. 2007;11:148-52.

130. Patel RM, Kandefer S, Walsh MC, Bell EF, Carlo WA, Laptook AR, Sanchez PJ, Shankaran S, Van Meurs KP, Ball MB, et al. Causes and timing of death in extremely premature infants from 2000 through 2011. N Engl J Med. 2015;372:331-40.

131. Fledelius $\mathrm{HC}$, Jensen $\mathrm{H}$. Late subsequent ocular morbidity in retinopathy of prematurity patients, with emphasis on visual loss caused by insidious 'involutive' pathology: an observational series. Acta Ophthalmol. 2011:89:316-23.

132. Anderson MF, Ramasamy B, Lythgoe DT, Clark D. Choroidal thickness in regressed retinopathy of prematurity. Eye (Lond). 2014;28:1461-8.

133. Hansen RM, Moskowitz A, Akula JD, Fulton AB. The neural retina in retinopathy of prematurity. Prog Retin Eye Res. 2017:56:32-57.

134. Wu WC, Shih CP, Wang NK, Lien R, Chen YP, Chao AN, Chen KJ, Chen TL, Hwang YS, Lai CC, et al. Choroidal thickness in patients with a history of retinopathy of prematurity. JAMA Ophthalmol. 2013;131:1451-8.

135. Moreno TA, O'Connell RV, Chiu SJ, Farsiu S, Cabrera MT, Maldonado RS, Tran-Viet D, Freedman SF, Wallace DK, Toth CA. Choroid development and feasibility of choroidal imaging in the preterm and term infants utilizing SD-OCT. Invest Ophthalmol Vis Sci. 2013:54:4140-7.

136. Park KA, Oh SY. Analysis of spectral-domain optical coherence tomography in preterm children: retinal layer thickness and choroidal thickness profiles. Invest Ophthalmol Vis Sci. 2012;53:7201-7.

137. Erol MK, Coban DT, Ozdemir O, Dogan B, Tunay ZO, Bulut M. Choroidal thickness in infants with retinopathy of prematurity. Retina. 2016;36:1191-8.

138. Hardy P, Nuyt AM, Abran D, St-Louis J, Varma DR, Chemtob S. Nitric oxide in retinal and choroidal blood flow autoregulation in newborn pigs: interactions with prostaglandins. Pediatr Res. 1996:39:487-93.

139. Dumont I, Hardy P, Peri KG, Hou X, Molotchnikoff S, Varma DR, Chemtob S. Regulation of endothelial nitric oxide synthase by $P G D(2)$ in the developing choroid. Am J Phys Heart Circ Phys. 2000;278:H60-6.

140. Hardy P, Peri KG, Lahaie I, Varma DR, Chemtob S. Increased nitric oxide synthesis and action preclude choroidal vasoconstriction to hyperoxia in newborn pigs. Circ Res. 1996;79:504-11.

141. Sharif NA, Davis TL, Williams GW. Ocular hypotensive DP-class prostaglandin receptor affinities determined by quantitative autoradiography on human eye sections. J Ocul Pharmacol Ther. 2005;21:121-32.

142. Sharif NA, Williams GW, Davis TL. Pharmacology and autoradiography of human DP prostanoid receptors using [(3)H]-BWA868C, a DP receptorselective antagonist radioligand. $\mathrm{Br} J$ Pharmacol. 2000;131:1025-38.

143. Hardy P, Dumont I, Bhattacharya M, Hou X, Lachapelle P, Varma DR, Chemtob S. Oxidants, nitric oxide and prostanoids in the developing ocular vasculature: a basis for ischemic retinopathy. Cardiovasc Res. 2000;47:489-509. 
144. Beauchamp MH, Sennlaub F, Speranza G, Gobeil F Jr, Checchin D, Kermorvant-Duchemin E, Abran D, Hardy P, Lachapelle P, Varma DR, Chemtob S. Redox-dependent effects of nitric oxide on microvascular integrity in oxygen-induced retinopathy. Free Radic Biol Med. 2004;37:1885-94.

145. Niki E. Lipid peroxidation: physiological levels and dual biological effects. Free Radic Biol Med. 2009:47:469-84.

146. Gilroy DW, Colville-Nash PR, Willis D, Chivers J, Paul-Clark MJ, Willoughby DA. Inducible cyclooxygenase may have anti-inflammatory properties. Nat Med. 1999:5:698-701.

147. Levonen AL, Dickinson DA, Moellering DR, Mulcahy RT, Forman HJ, Darley-Usmar VM. Biphasic effects of 15-deoxy-delta(12,14)-prostaglandin $\mathrm{J}(2)$ on glutathione induction and apoptosis in human endothelial cells. Arterioscler Thromb Vasc Biol. 2001;21:1846-51.

148. Marques N, Barros S, Miranda A, Cardoso J, Parreira S, Fonseca T, Donaire N, Campos N. Evaluation of retinal, choroidal thickness and retinal pigmented epithelium using Cirrus SD-OCT in Portuguese children with history of preterm birth. Vis Pan-Am. 2016;15:56-60.

149. Cook A, White S, Batterbury M, Clark D. Ocular growth and refractive error development in premature infants with or without retinopathy of prematurity. Invest Ophthalmol Vis Sci. 2008;49:5199-207.

150. Nickla DL, Wallman J. The multifunctional choroid. Prog Retin Eye Res. 2010;29:144-68.

151. Early Treatment For Retinopathy Of Prematurity Cooperative G. Revised indications for the treatment of retinopathy of prematurity: results of the early treatment for retinopathy of prematurity randomized trial. Arch Ophthalmol. 2003;121:1684-94.

152. Ospina LH, Lyons CJ, Matsuba C, Jan J, McCormick AQ. Argon laser photocoagulation for retinopathy of prematurity: long-term outcome. Eye. 2005;19:1213-8.

153. Ferrara N, Hillan KJ, Gerber HP, Novotny W. Discovery and development of bevacizumab, an anti-VEGF antibody for treating cancer. Nat Rev Drug Discov. 2004;3:391-400.

154. Hurwitz H, Fehrenbacher L, Novotny W, Cartwright T, Hainsworth J, Heim W, Berlin J, Baron A, Griffing S, Holmgren E, et al. Bevacizumab plus irinotecan, fluorouracil, and leucovorin for metastatic colorectal cancer. N Engl J Med. 2004;350:2335-42.

155. Pertl L, Steinwender G, Mayer C, Hausberger S, Poschl EM, Wackernagel W, Wedrich A, El-Shabrawi Y, Haas A. A systematic review and metaanalysis on the safety of vascular endothelial growth factor (VEGF) inhibitors for the treatment of retinopathy of prematurity. PLoS One. 2015;10:e0129383.

156. Salman AG, Said AM. Structural, visual and refractive outcomes of intravitreal aflibercept injection in high-risk prethreshold type 1 retinopathy of prematurity. Ophthalmic Res. 2015;53:15-20.

157. Micieli JA, Surkont M, Smith AF. A systematic analysis of the off-label use of bevacizumab for severe retinopathy of prematurity. Am J Ophthalmol. 2009;148:536-43. e532

158. Fierson WM, American Academy of Pediatrics Section on O, American Academy of $\mathrm{O}$, American Association for Pediatric O, Strabismus, American Association of Certified O. Screening examination of premature infants for retinopathy of prematurity. Pediatrics. 2013;131:189-95.

159. Spandau U, Tomic Z, Ewald U, Larsson E, Akerblom H, Holmstrom G. Time to consider a new treatment protocol for aggressive posterior retinopathy of prematurity? Acta Ophthalmol. 2013;91:170-5.

160. Mintz-Hittner HA, Kennedy KA, Chuang AZ, Group B-RC. Efficacy of intravitreal bevacizumab for stage 3+ retinopathy of prematurity. N Engl J Med. 2011;364:603-15.

161. Chen YH, Chen SN, Lien RI, Shih CP, Chao AN, Chen KJ, Hwang YS, Wang NK, Chen YP, Lee $\mathrm{KH}$, et al. Refractive errors after the use of bevacizumab for the treatment of retinopathy of prematurity: 2-year outcomes. Eye (Lond). 2014;28:1080-6. quiz 1087

162. Geloneck MM, Chuang AZ, Clark WL, Hunt MG, Norman AA, Packwood EA, Tawansy KA, Mintz-Hittner HA. Refractive outcomes following bevacizumab monotherapy compared with conventional laser treatment: a randomized clinical trial. JAMA Ophthalmol. 2014;132:1327-33.

163. Harder BC, Schlichtenbrede FC, von Baltz S, Jendritza W, Jendritza B, Jonas JB. Intravitreal bevacizumab for retinopathy of prematurity: refractive error results. Am J Ophthalmol. 2013;155:1119-24. e1111

164. Darlow BA, Ells AL, Gilbert CE, Gole GA, Quinn GE. Are we there yet? Bevacizumab therapy for retinopathy of prematurity. Arch Dis Child Fetal Neonatal Ed. 2013;98:F170-4.
165. Jo N, Mailhos C, Ju M, Cheung E, Bradley J, Nishijima K, Robinson GS, Adamis AP, Shima DT. Inhibition of platelet-derived growth factor B signaling enhances the efficacy of anti-vascular endothelial growth factor therapy in multiple models of ocular neovascularization. Am J Pathol. 2006;168:2036-53.

166. Nishijima K, Ng YS, Zhong L, Bradley J, Schubert W, Jo N, Akita J, Samuelsson SJ, Robinson GS, Adamis AP, Shima DT. Vascular endothelial growth factor-A is a survival factor for retinal neurons and a critical neuroprotectant during the adaptive response to ischemic injury. Am J Pathol. 2007;171:53-67.

167. Saint-Geniez M, Maharaj AS, Walshe TE, Tucker BA, Sekiyama E, Kurihara T, Darland DC, Young MJ, D'Amore PA. Endogenous VEGF is required for visual function: evidence for a survival role on muller cells and photoreceptors. PLoS One. 2008:3:e3554

168. Ford KM, Saint-Geniez M, Walshe TE, D'Amore PA. Expression and role of VEGF-a in the ciliary body. Invest Ophthalmol Vis Sci. 2012;53:7520-7.

169. Kurihara T, Westenskow PD, Bravo S, Aguilar E, Friedlander M. Targeted deletion of Vegfa in adult mice induces vision loss. J Clin Invest. 2012;122:4213-7.

170. Morin J, Luu TM, Superstein R, Ospina LH, Lefebvre F, Simard MN, Shah V, Shah PS, Kelly EN, Canadian Neonatal N, the Canadian Neonatal Follow-Up Network I. Neurodevelopmental outcomes following bevacizumab injections for retinopathy of prematurity. Pediatrics. 2016;137(4):e20153218.

171. Lofqvist C, Andersson E, Sigurdsson J, Engstrom E, Hard AL, Niklasson A, Smith LE, Hellstrom A. Longitudinal postnatal weight and insulin-like growth factor I measurements in the prediction of retinopathy of prematurity. Arch Ophthalmol. 2006;124:1711-8.

172. Lundgren P, Stoltz Sjostrom E, Domellof M, Kallen K, Holmstrom G, Hard AL, Smith LE, Lofqvist C, Hellstrom A. WINROP identifies severe retinopathy of prematurity at an early stage in a nation-based cohort of extremely preterm infants. PLoS One. 2013;8:e73256.

173. Diaz-Gomez NM, Domenech E, Barroso F. Breast-feeding and growth factors in preterm newborn infants. J Pediatr Gastroenterol Nutr. 1997;24:322-7.

174. Elmlinger MW, Grund R, Buck M, Wollmann HA, Feist N, Weber MM, Speer CP, Ranke MB. Limited proteolysis of the IGF binding protein-2 (IGFBP-2) by a specific serine protease activity in early breast milk. Pediatr Res. 1999;46:76-81.

175. Hansen-Pupp I, Engstrom E, Niklasson A, Berg AC, Fellman V, Lofqvist C, Hellstrom A, Ley D. Fresh-frozen plasma as a source of exogenous insulinlike growth factor-I in the extremely preterm infant. J Clin Endocrinol Metab. 2009;94:477-82.

176. Dani C, Poggi C, Bresci C, Corsini I, Frosini S, Pratesi S. Early fresh-frozen plasma transfusion decreases the risk of retinopathy of prematurity. Transfusion. 2014:54:1002-7.

177. Vanhaesebrouck S, Daniels H, Moons L, Vanhole C, Carmeliet P, De Zegher F. Oxygen-induced retinopathy in mice: amplification by neonatal IGF-I deficit and attenuation by IGF-I administration. Pediatr Res. 2009;65:307-10.

178. Fliesler SJ, Anderson RE. Chemistry and metabolism of lipids in the vertebrate retina. Prog Lipid Res. 1983;22:79-131.

179. Connor KM, SanGiovanni JP, Lofqvist C, Aderman CM, Chen J, Higuchi A, Hong S, Pravda EA, Majchrzak S, Carper D, et al. Increased dietary intake of omega-3-polyunsaturated fatty acids reduces pathological retinal angiogenesis. Nat Med. 2007;13:868-73.

180. Qawasmi A, Landeros-Weisenberger A, Bloch MH. Meta-analysis of LCPUFA supplementation of infant formula and visual acuity. Pediatrics. 2013;131:e262-72.

181. Ritter MR, Banin E, Moreno SK, Aguilar E, Dorrell MI, Friedlander M. Myeloid progenitors differentiate into microglia and promote vascular repair in a model of ischemic retinopathy. J Clin Invest. 2006;116:3266-76.

182. Otani A, Kinder K, Ewalt K, Otero FJ, Schimmel P, Friedlander M. Bone marrow-derived stem cells target retinal astrocytes and can promote or inhibit retinal angiogenesis. Nat Med. 2002;8:1004-10.

183. Nakagawa Y, Masuda H, Ito R, Kobori M, Wada M, Shizuno T, Sato A, Suzuki T, Kawai K, Asahara T. Aberrant kinetics of bone marrow-derived endothelial progenitor cells in the murine oxygen-induced retinopathy model. Invest Ophthalmol Vis Sci. 2011;52:7835-41.

184. Stitt AW, O'Neill CL, O'Doherty MT, Archer DB, Gardiner TA, Medina RJ. Vascular stem cells and ischaemic retinopathies. Prog Retin Eye Res. 2011;30:149-66.

185. Medina RJ, O'Neill CL, Humphreys MW, Gardiner TA, Stitt AW. Outgrowth endothelial cells: characterization and their potential for reversing ischemic retinopathy. Invest Ophthalmol Vis Sci. 2010;51:5906-13.

186. Machalinska A, Modrzejewska M, Kotowski M, Dziedziejko V, Kucia M, Kawa M, Safranow K, Baskiewicz-Masiuk M, Modrzejewska A, Karczewicz D, et al. 
Circulating stem cell populations in preterm infants: implications for the development of retinopathy of prematurity. Arch Ophthalmol. 2010;128:1311-9.

187. Machalinska A, Modrzejewska M, Kawa M, Paczkowska E, Dziedziejko V, Safranow K, Lubinski W, Machalinski B. Potential contribution of mobilized circulating endothelial progenitor cells to development of retinal neovascularization in preterm infants with ROP. Klin Ocz. 2013:115:194-8.

188. Chowers I, Banin E, Hemo Y, Porat R, Falk H, Keshet E, Pe'er J, Panet A. Gene transfer by viral vectors into blood vessels in a rat model of retinopathy of prematurity. Br J Ophthalmol. 2001;85:991-5.

189. Dejneka NS, Rex TS, Bennett J. Gene therapy and animal models for retinal disease. Dev Ophthalmol. 2003;37:188-98.

190. Auricchio A, Behling KC, Maguire AM, O'Connor EM, Bennett J, Wilson JM, Tolentino MJ. Inhibition of retinal neovascularization by intraocular viralmediated delivery of anti-angiogenic agents. Mol Ther. 2002;6:490-4.

Submit your next manuscript to BioMed Central and we will help you at every step:

- We accept pre-submission inquiries

- Our selector tool helps you to find the most relevant journal

- We provide round the clock customer support

- Convenient online submission

- Thorough peer review

- Inclusion in PubMed and all major indexing services

- Maximum visibility for your research

Submit your manuscript at www.biomedcentral.com/submit
Biomed Central 